\title{
Pengaruh Pembiayaan Mudharabah, Musyarakah dan Murabahah Terhadap Profitabilitas Bank Umum Syariah
}

\author{
Dinar Mega Silvia Sari ${ }^{\left.1^{*}\right)}$, Sri Suartini ${ }^{2)}$, Isro'iyatul Mubarokah ${ }^{3)}$, Nanu Hasanuh ${ }^{4)}$ \\ ${ }^{1,2,3,4}$ Fakultas Ekonomi dan Bisnis, Universitas Singaperbangsa Karawang \\ *Email korenpondensi: silviasaridinarmega@gmail.com
}

\begin{abstract}
This study aims to analyze the effect of mudharabah, musyarakah, and murabahah financing on the level of profitability at the bank by using the Return on Assets (ROA) ratio simultaneously and partially. The sample used in this study was 42 data from the results of outlier data with a total of 52 sample data with the study population using 7 (seven) Islamic commercial banks until 2019. The data analysis method used in this study was multiple linear regression from panel data. The results of this study indicate that partially mudharabah financing has no significant negative effect on the level of profitability, while musharaka partially has a negative effect on the level of profitability. Murabahah financing has a significant positive effect on profitability.
\end{abstract}

Keywords: Mudharabah, Musyarakah, Murabahah, dan Profitability

Saran sitasi: Sari, D. M. S., Suartini, S., Mubarokah, I., \& Hasanuh, N. (2021). Pengaruh Pembiayaan Mudharabah, Musyarakah dan Murabahah Terhadap Profitabilitas Bank Umum Syariah. Jurnal Ilmiah Ekonomi Islam, 7(01), 241-249. doi: http://dx.doi.org/10.29040/jiei.v7i1.1850

\section{DOI: http://dx.doi.org/10.29040/jiei.v7i1.1850}

\section{PENDAHULUAN}

Negara Indonesia merupakan negara dengan jumlah masyarakatnya yang sebagian besar beragama muslim. Dimana masyarakatnya dapat mengikuti perkembangan ekonomi islam yang terjadi di Dunia. Masyarakat Indonesia sebagian besar masyarakatnya berkiprah di dunia perdagangan dan bisnis. Maka Negara Indonesia memiliki banyak bank yang mendasarkan pengolahanya pada prinsip syariah dengan landasan ekonomi islami. Salah satu pedoman yang digunakan oleh umat muslim untuk berperilaku dalam segala aspek-aspek kehidupan di Dunia yaitu prinsip syariah. Indonesia masih tetap berdaya tahan mengalami pertumbuhan perekonomian dunia yang tengah melambat. Perkembangannya ditandai dengan kemunculan ekonomi islam yang mampu menyumbangkan pemikiran dengan mengembangkan ilmu ekonomi yang islami. Walaupun sedang berada ditengah-tengah krisis perekonomian, ada salah satu perbankan yang masih tetap bertahan adalah perbankan syariah yang berlandaskan ilmu ekonomi islam. Perbankan syariah memiliki salah satu keunggulan yang terdapat pada bank syariah adalah dengan adanya sistem bagi hasil atau akad. Sistem bagi hasil atau akad pada bank syariah merupakan perjanjian kedua belah pihak antara nasabah dengan bank syariah untuk mendapatkan keuntungan. Kegiatan perbankan syariah yang diatur dengan peraturan pemerintah Undang-Undang No. 7 Tahun 1992 Tentang perbankan, dimana perbankan dengan bagi hasil diakomodasi. Hal tersebut tentu saja dapat memberikan wadah agar dapat mengembangkan dan mengoperasionalkan perbankan berdasarkan prinsip syariah. UndangUndang tersebut kemudian direvisi dengan UndangUndang No. 10 Tahun 1998 Tentang Perbankan, jika dilihat dari segi landasan maupun operasionalnya pada bank syariah di Indonesia dengan memiliki landasan hukum yang jelas dan kuat. Perbankan syariah dapat membantu perkembangan perekonomian dunia khususnya di Negara Indonesia. Sehingga dapat dikembangkan untuk bersaing dalam dunia bisnis global. Karena pada dasarnya perbankan syariah dapat menjadi salah satu acuan pemerintah yang bermanfaat untuk membantu pengelolaan dana masyarakatnya. Lembaga keuangan meningkatkan nilai transaksi yang berbasis syariah. Peningkatkan ini ditandai dengan meningkatkan akuntansi syariah, 
sehingga dapat diterimanya prinsip-prinsip syariah di dunia internasional.

Salah satu keberhasilan bank dalam menghasilkan laba setiap periodenya dapat dilihat dari profitabilitas suatu bank yang diukur menggunakan Return On Assets (ROA). Salah satu fenomena yang terjadi di perbankan syariah adalah profitabilitas perbankan syariah. Seperti yang dialami oleh PT Bank Muamalat terjadi fenomena yang seharusnya ROA dalam setiap tahunnya mengalami kenaikan. Tetapi, ROA pada Bank Muamalat mengalami kenaikan dan penurunan secara fluktuatif. Tercatat ROA Pada tahun 2017 mengalami penurunan sebesar 0,04, pada tahun 2018 ROA mengalami kenaikan sebesar 0,08 dan pada tahun 2019 ROA mengalami penurunan kembali sebesar 0,05. Ditemukan fenomena pada PT Bank Muamalat pada tahun 2019 terjadi penurunan ROA yang disebabkan karena naiknya non perfoming financing/NPF Muamalat Indonesia yang melebihi angka 5\% sesuai bank Indonesia. Jika nilai NPF naik menandakan banyak kredit bermasalah dan jika kredit bermasalah maka akan menyebabkan turunnya pendapatan atau profitabilitas yang menyebabkan menurunnya ROA Bank Muamalat Indonesia. Peningkatan profitabilitas setiap tahunnya harus dapat dilakukan, salah satu caranya adalah dengan meningkatkan dana dari sumber yang tersedia. Salah satu cara dalam upaya peningkatan sumber dana yang dilakukan oleh bank syariah yang ditempuh dengan menghimpun maupun dalam pengelolaan dana dari masyarakat, maupun dana yang telah dihimpun oleh bank syariah kemudian akan disalurkannya kembali kepada nasabah (Irmawati, 2014). Bank syariah memiliki tugas pokok usaha yaitu dengan menghimpun dana dan menyalurkannya kepada masyarakat dengan bentuk kredit atau dalam bentuk-bentuk lainnya yang berlandaskan prinsipprinsip syariah. Berbagai kegiatan usaha suatu bank yakni selain menghimpun dana, maupun penyalur dana,atau melakukan suatu pembiayaan dan pinjaman, serta pendapatan dan jasa suatu bank syariah. Salah satu pembiayaan tersebut yakni pada pembiayaan bank syariah adalah pembiayaan mudharabah, musyarakah dan murabahah. Pembiayaan tersebut dapat mempengaruhi suatu profitabilitas pada bank syariah. Dalam meningkatkan laba, bank tersebut tidak dapat terlepas dari pembiayaan-pembiayaan yang digunakan untuk pengelolaan dana sebagai gambaran kinerja suatu bank syariah. Pembiayaan tersebut memberikan dampak yang positif pada laba suatu bank. Apabila bank tersebut setiap tahunnya memberikan kinerja yang baik sehingga akan memberikan dampak dengan meningkatnya suatu laba perusahaan dengan tingkat profitabilitas suatu bank yang meningkat. Bank syariah tidak terlepas dari tugas utamanya yakni sebagai pihak pengeloaan dana, baik dalam penyimpanan atau sebagai penyalur dana kepada masyarakat baik dalam bentuk kredit maupun bentukbentuk lainnya sehingga bermanfaat bagi masyarakat tersebut.

Menurut Karim (2010: 204) pembiayaan mudharabah merupakan salah satu bentuk kontrak antara kedua belah pihak, yang mana pemilik modal sebagai pihak pertama yang akan mempercayakan pihak kedua untuk mengelola sumber jumlah dana modalnya dan pihak kedua yang berperan sebagai pelaksana usaha, yang tujuannya adalah untuk sama-sama mendapatkan keuntungan. Sedangkan menurut Sudarsono (2008: 76) pembiayaan mudharabah adalah salah satu bentuk kerjasama usaha antara kedua belah pihak, memiliki fungsi penyedia seluruh modal sebagai tugas pihak pertama, sedangkan pihak kedua atau disebut mudharib sebagai pengelola. Sedangkan pembiayaan musyarakah merupakan bentuk kerja sama antara kedua belah pihak atau lebih dalam menjalankan suatu usaha yang mana masing-masing pihak memiliki keahlian dengan persetujuan atau kesepakatan bersama antara kedua belah pihak untuk berkontribusi, dimana dalam menjalankan suatu usaha pasti terdapat suatu keuntungan dan kerugian, dimana keuntungan mauapun kerugian tersebut ada dalam suatu kontrak yang telah dibagi secara bersamasama sesuai dengan modal yang telah disepakati (Dahlan, 2012: 169). Apabila suatu pendapatan atau pembiayaan musyarakah yang diberikan oleh bank sebagai penyaluran dana, maka akan menghasilkan tingginya tingkat profitabilitas yang diperoleh oleh suatu bank karena pendapatan bank akan meningkat. Sedangkan pembiayaan murabahah merupakan suatu proses kegiatan jual beli pada harga pokok dengan tambahan keuntungan yang disepakati. Dalam hal ini penjual harus dapat memberitahukan harga pokok yang telah dia beli dan telah ditambahkan keuntungan yang sesuai yang telah diinginkannya (Kasmir, 2002). Sedangkan akad murabahah adalah suatu proses kegiatan jual beli barang dengan menggunakan alat tukar yang disertai dengan nilai tambahan yang telah ditentukan (resale with a stated profit). 
Pembiayaan murabahah pada perbankan syariah yakni bank syariah bertindak sebagai penjual, sedangkan nasabah bertindak sebagai pembeli. Pembiayan mudharabah, musyarakah dan murabahah tidak dapat dipisahkan dalam suatu kinerja suatu bank syariah. Pembiayan tersebut dapat mempengaruhi suatu profitabilitas suatu bank syariah.

Berdasarkan penelitian pada Bank Umum Syariah, maka dilakukan penelitian kembali untuk menguji pengaruh pembiayaan mudharabah , musyarakah dan muarabahah terhadap profitabilitas. Maka dari itu peneliti tertarik untuk melakukan penelitian kembali dengan judul “ Pengaruh Pembiayaan Mudharabah, Musyarakah, dan Murabahah terhadap Profitabilitas pada Bank Umum Syariah periode 2015-2019.

\section{Rumusan Masalah}

Berdasarkan uraian latar belakang yang telah dikemukakan sebelumnya, untuk itu rumusan masalah pada tulisan ini adalah sebagai berikut:

a. Seberapa besar pengaruh pembiayaan mudharabah terhadap profitabilitas pada bank umum syariah periode 2015-2019?

b. Seberapa besar pengaruh pembiayaan musyarakah terhadap profitabilitas pada bank umum syariah periode 2015-2019?

c. Seberapa besar pengaruh pembiayaan murabahah terhadap profitabilitas pada bank umum syariah periode 2015-2019?

d. Seberapa besar pengaruh pembiayaan mudharabah, musyarakah dan murabahah terhadap profitabilitas pada bank umum syariah periode 2015-2019?

\section{Tujuan penelitian}

Berdasarkan perumusan masalah diatas maka tujuan penelitian ini adalah untuk menentukan:

a. Untuk mengetahui, menganalisis, dan mendeskripsikan besarnya pengaruh pembiayaan mudharabah terhadap profitabilitas pada bank umum syariah periode 2015-2019?

b. Untuk mengetahui, menganalisis, dan mendeskripsikan besarnya pengaruh pembiayaan musyarakah terhadap profitabilitas pada bank umum syariah periode 2015-2019.

c. Untuk mengetahui, menganalisis, dan mendeskripsikan besarnya pengaruh pembiayaan murabahah terhadap profitabilitas pada bank umum syariah periode 2015-2019.

d. Untuk mengetahui, menganalisis, dan mendeskripsikan besarnya pengaruh pembiayaan mudharabah, musyarakah dan murabahah terhadap profitabilitas pada bank umum syariah periode 2015-2019.

\section{LANDASAN TEORI}

\section{Bank Syariah}

Menurut Salman (2017:98) bank syariah merupakan badan usaha yang memiliki tugas untuk menghimpun dana masyarakat dalam bentuk tabungan dan menyalurkan kepada masyarakat dalam bentuk pembiayaan atau bentuk-bentuk lain. Menurut Undang-Undang No. 21 tahun 2008 tentang bank, bank syariah mendefinisikan bahwa bank memiliki tugas yang tujuanya adalah menjalankan kegiatan usaha berdasarkan prinsip-prinsip syariah yang diatur fatwa MUI seperti prinsip keadilan dan keseimbangan (,adl wa tawazun), kemaslahatan (mashlahah), universalisme (alamiyah), serta tidak mengandung gharar, maysir, riba, zalim, dan objek yang haram bank syariah. Bank syariah adalah segala bentuk kegiatan yang berlandaskan prinsip syariah islami. Bank syariah berdiri atas prakarsa oleh Majelis Ulama Indonesia (MUI) sekitar tahun 1990. Bank syariah dengan sistem operasinya berdasarkan bagi hasil.

\section{Profitabilitas}

Rasio profitabilitas merupakan rasio yang memiliki tujuan untuk mengetahui seberapa besar kemampuan perusahaan/ perbankan dalam menghasilkan laba selama periode tertentu dan dapat memberikan gambaran mengenai tingkat efektivitas manajemen di dalam melaksanakan kegiatan operasinya. Rasio profitabilitas yang digunakan dalam penelitian ini yakni dapat diukur dengan menggunakan Return On Assets (ROA). Menurut Munawir (2010:89) ROA adalah "Salah satu bentuk rasio yang digunakan pada rasio profitabilitas untuk dapat mengukur seberapa besar kemampuan perusahaan dengan keseluruhan sumber dana yang telah digunakan untuk operasi perusahaan dalam menghasilkan laba suatu perusahaan"

\section{Pembiayaan mudharabah}

Menurut Ismail (2013) mudharabah merupakan "suatu akad perjanjian antara kedua belah pihak atau lebih untuk melakukan kerja sama dalam menjalankan suatu usaha yang dapat menguntungkan”. Dalam melakukan akad ini, pihak lembaga keuangan syariah bertindak sebagai shahibul maal yang menempatkan modal sebesar $100 \%$ sedangkan nasabah bertindak sebagai mudharib yaitu pengelola 
dana. Nisbah bagi hasil dihitung sesuai dengan kesepakatan bersama. Mudharabah merupakan bentuk perjanjian kedua belah pihak atau lebih dengan tujuan sama-sama menguntungkan. Sedangkan menurut Nurhayati dan Wasilah (2015) menjelaskan pembiayaan mudharabah adalah bentuk akad kerja sama usaha antara dua belah pihak yang dimana satu pihak sebagai penyedia seluruh sumber dana (pemilik dana/shahibul maal) dan pihak lainnya sebagai mengelola dana (pengelola dana/mudharib), dan keuntungan tersebut dibagi atas dasar nisbah bagi hasil atau akad yang sesuai yang telah disepakati. Kerugian finansial hanya ditanggung oleh pemilik dana. Mudharabah merupakan stransaksi yang berlandaskan kepercayaan, yakni kepercayaan dengan pemilik dana kepada pengelola dana. Karena bentuk kepercayaan merupakan unsur penting didalam akad mudharabah atau dalam bahasa inggris disebut trust financing. Bentuk kepercayaan sangat penting karena pemilik dana tidak bisa ikut campur dalam manajemen perusahaan yang telah dibiayai dengan dana dari pemilik dana tersebut. Apabila terjadi kerugian, maka yang akan menanggung kerugian hanya pemilik dana. Sedangkan pengelola dana tidak menanggung kerugian. Terkecuali jika kerugian tersebut terjadi karena kelalaian atau ada unsur kesengajaan atau bahkan pelanggaran yang dilakukan oleh pengelola dana.pengelola dana hanya menanggung resiko berupa waktu, tenaga dan pikiran yang tercurahkan selama mengelola proyek tersebut. Sistem mudharabah dapat memberikan keringenan kepada sesama manusia. Dengan begitu, mudharabah adalah bentuk kegiatan antara kedua belah pihak yang dapat mengambil manfaat dari kerja sama antara pemilik dana dan pengelola dana. Sehingga dapat tercipta kerja sama dan kesejahteraan umat.

\section{Pembiayaan Musyarakah}

Menurut Nurhayati dan Wasilah (2015, hlm.150) musyarakah merupakan suatu bentuk akad kerja sama antara kedua belah pihak atau lebih untuk menjalankan suatu usaha tertentu. Masing - masing pihak tersebut dapat memberikan kontribusi modal dengan memberikan keuntungan yang telah dibagi berdasarkan kesepakatan bersama-sama. Sedangkan besarnya kerugian ditanggung berdasarkan modal yang telah dikontribusikan. Pembiayaan musyarakah sebagai suatu akad kerja sama kedua belah pihak atau lebih dalam menjalankan suatu usaha yang bertujuan dari masing-masing pihak yang bersangkutan mampu berkontribusi dalam bentuk dana berdasarkan kesepakatan bersama untuk menanggung keuntungan maupun resiko atau kerugian secara bersama-sama (Antonio, 2001, h. 90). Di dalam musyarakah, para mitra bersama-sama menyediakan dana modal untuk dapat mebiayai dan bekerja sama pada usaha tersebut. Penjelasan tersebut secara umum sesuai dengan pengertian musyarakah yang tercantum dalam Undang-Undang Republik Indonesia No. 21/2008 mengenai perbankan syariah yang menjelaskan mengenai bentuk kontribusi pihak yang terlibat disamping dalam bentuk dana dapat berupa barang perdagangan, kewiraswastaan, skill kepemilikan, peralatan hak paten, kepercyaan/reputasi, serta barang lain yang dapat dinilai dengan uang (Soemitra,2009, h. 83). Modal yang dikeluarkan harus bisa digunakan untuk bisa mencapai tujuan yang telah ditetapkan bersamasama. Sehingga modal tersebut tidak bisa disalahgunakan untuk kepentingan pribadi atau dipinjamkan pada pihak lain tanpa izin mitra.

\section{Pembiayaan Murabahah}

Menurut Antonio (2001) murabahah merupakan bentuk akad jual beli atas suatu barang tertentu dengan tambahan keuntungan yang telah disepakati. Penjual (bank) akan memberitahukan harga pokok dan berapa tambahan keuntungannya yang telah disepakati. Murabahah dengan penjualan yang biasa dilakukan dapat dibedakan dengan penjual secara jelas memberitahukan harga pokok barang tersebut dan besarnya keuntungan yang diinginkannya secara jelas kepada pembeli. Penjual dan pembeli dapat melakukan tawar-menawar atas besarnya keuntungan yang pada akhirnya diperoleh kesepakatan bersama. Kasmir (2002:223), "Murabahah adalah kegiatan jual beli dengan harga pokok dan tambahan keuntungan yang telah disepakati. Dalam hal ini penjual harus terlebih dahulu memberitahukan harga pokok yang dibeli ditambah keuntungan yang diinginkannya." Murabahah merupakan transaksi jual beli dimana kelebihan dari harga pokoknya merupakan keuntungan dari penjualan barang sehingga sesuai dengan syariah islam.

\section{METODE PENELITIAN}

\section{Jenis Penelitian}

Pada penelitian ini, penelitian ini menggunakan jenis penelitian kuantitatif. Penelitian kuantitatif merupakan penelitian yang berdasarkan data berupa angka-angka. Ruang lingkup pada penelitian ini terdiri dari variabel bebas (X) yakni pembiayaan 
mudharabah, musyarakah, dan murabahah dan variabel terikat (Y) yakni profitabilitas yang diukur dengan ROA ( Return On Assets).

\section{Populasi dan Sampel}

Populasi yang digunakan pada penelitian ini adalah Bank umum syariah yang terdaftar di Bursa Efek Indonesia (BEI) periode hingga 2019 yang berjumlah 7 ( Tujuh) bank syariah yaitu Bank Syariah Muamalat, Bank Mandiri Syariah, Bank BRI Syariah, Bank BNI Syariah, Bank Victoria Syariah, Bank Bukopin Syariah dan Bank BCA Syariah. Metode pengambilan sampel yaitu dengan menggunakan non-probability sampling. Non probability sampling adalah teknik pengumpulan data yang memberikan peluang bagi setiap anggota untuk menjadi sampel yang dipilih.

\section{Metode Pengumpulan Data}

Pada penelitian ini, peneliti menggunakan metode pengumpulan data yaitu dengan menggunakan studi kepustakaan dan teknik dokumentasi. Studi kepustakaan merupakan teknik pengumpulan data yang diambil secara literatul yang berupa dari jurnal-jurnal,buku-buku dan lain-lain yang masih relevan. Sedangkan teknik dokumentasi dilakukan dengan mendownload data-data yang berupa laporan keuangan yang diperoleh dari media internet. Teknik analisis data menggunakan analisis regresi linear berganda. Dengan melakukan uji aumsi klasik dan uji statistik. Teknik analisis data yang digunakan adalah uji asumsi klasik ( uji normalitas, uji autokorelasi, uji multikolinearitas, dan uji Heteroskedastisitas), uji statistik (Uji F, uji T, Uji dan analisis deskriptif (Koefisien determinasi, dan uji analisis regresi linear berganda).

\section{Uji outlier}

Outlier data merupakan salah satu cara dalam mengatasi data tidak normal dalam uji normalitas. Apabila data tidak normal, bisa melakukan penyebuhan data dengan menggunakan outlier data.

Sebelum melakukan uji outlier terdapat 52 data sampel, tetapi setelah melakukan uji outlier, data menjadi 42 sampel.

\section{HASIL DAN PEMBAHASAN}

\subsection{Hasil Penelitian \\ Uji Asumsi Klasik}

a. Uji normalitas

Dalam penelitian ini, sebuah model regresi variabel independen dan variabel dependen memiliki distribusi normal atau tidak normal. Maka penelitian ini dilakukan dengan menggunakan uji Kolmogorov$S$ Minorvest.

Berikut uji normalitas pada bank umum syariah dapat dilihat dibawah ini:

\section{Tabel 1}

Hasil Uji Normalitas

One-Sample Kolmogorov-Smirnov Test

\begin{tabular}{|cc|c|}
\hline & & $\begin{array}{c}\text { Unstandardized } \\
\text { Residual }\end{array}$ \\
\hline & $\mathrm{N}$ & 42 \\
Normal & Mean & .0000000 \\
Parameters & & .57311807 \\
Most & Std. Deviation & .112 \\
Extreme & Absolute & .112 \\
Differences & Positive & -.101 \\
Kolmogorov-Smirnov Z & .724 \\
Asymp. Sig. (2-tailed) & .670 \\
\hline \multicolumn{2}{|c|}{ a. Test distribution is Normal. } \\
\hline \multicolumn{2}{|c|}{} \\
\hline
\end{tabular}

Berdasarkan tabel diatas diperoleh nilai asymp.Sig (2-tailed) dari hasil uji KolmogorovSmirnov sebesar 0.670 dengan tingkat kekeliuran 0,05 maka dapat disimpulkan bahwa model regresi berdistribusi normal.

\section{b. Uji multikolonieritas}

Uji Multikolinieritas menunjukan bagaimana hubungant antara masing-masing variabel independen pada model regresi. Apabila ditemukan adanya multikolinieritas akan ditandai dengan nilai koefisien determinasi yang sangat besar. Tetapi pada pengujian parsial koefisien regresi tidak ditemukan ataupun kecil kemungkinan tidak ditemukan akan sedikit sekali koefisien regresi yang signifikan. Pada penelitian ini digunakan nilai variance inflation factors (VIF) sebagai indikator ditemukan atau tidaknya multikolinieritas diantara variabel independen.

Tabel 2

\section{Hasil Uji Multikolonieritas} Coefficients $^{\mathbf{a}}$

\begin{tabular}{|c|c|c|c|c|c|c|c|}
\hline \multirow[b]{2}{*}{ Model } & \multicolumn{2}{|c|}{$\begin{array}{l}\text { Unstandardized } \\
\text { Coefficients }\end{array}$} & \multirow{2}{*}{\begin{tabular}{c|}
$\begin{array}{c}\text { Standardized } \\
\text { Coofficients }\end{array}$ \\
Beta \\
\end{tabular}} & \multirow[b]{2}{*}{$T$} & \multirow[b]{2}{*}{ Sig. } & \multicolumn{2}{|c|}{$\begin{array}{l}\text { Collinearity } \\
\text { Statistics }\end{array}$} \\
\hline & B & Std. Error & & & & Tolerance & VIF \\
\hline '(Constant) & .867 & .135 & & 6.417 & .000 & & \\
\hline Mudharabah & .000 & .000 & -.172 & $-1,223$ & .229 & 958 & 1.044 \\
\hline Musyarakah & -.002 & .001 & -.316 & -2.215 & .033 & 930 & 1.076 \\
\hline Murabahah & .003 & .001 & .365 & 2.613 & .013 & 968 & 1.033 \\
\hline
\end{tabular}

Berdasarkan tabel diatas dapat diketahui nilai tolerance dan VIF untuk masing-masing variabel yaitu sebagai berikut. Untuk variabel mudharabah sebesar $0,958>0,10$ dan nilai VIF sebesar $1,044<0,10$ 
sehingga variabel mudharabah dinyatakan tidak terjadi multikolieritas. Selajutnya, nilai tolerance untuk variabel musyarakah sebesar 0,930 > 0,10 dan nilai VIF sebesar $1,076<0,10$, sehingga variabel musyarakah tidak terjadi multikolieritas. Dan nilai tolerance untuk variabel murabahah sebesar $0.968>$ 0,10 dan nilai VIF sebesar $1,033<0,10$, sehingga variabel murabahah tidak terjadi multikolinearitas. Maka dapat disimpulkan bahwa tidak terjadi multikolinearitas antara variabel independen.

c. Uji heteroskedastistas

\section{Tabel 3}

Uji Heteroskedastistas (Uji Glejser) Coefficients $^{\mathrm{a}}$

\begin{tabular}{|c|c|c|c|c|c|}
\hline \multirow[b]{2}{*}{ Model } & \multicolumn{2}{|c|}{ Unstandardixed Coefficients } & \multirow{2}{*}{$\begin{array}{c}\text { Standardinod } \\
\text { Coefficienta }\end{array}$} & \multirow[b]{2}{*}{$T$} & \multirow[b]{2}{*}{ Sig } \\
\hline & \begin{tabular}{l|l}
$\mathrm{B}$ \\
\end{tabular} & Std. Error & & & \\
\hline 1 (Constain) & 480 & .067 & & 7.285 & .000 \\
\hline Modharabah & $-7.698 \mathrm{E}-5$ & .000 & -.077 & -478 & .635 \\
\hline Musyarakah & .000 & .000 & $4,07 \mathrm{k}$ & -478 & .635 \\
\hline Murabahah & 001 & .001 & 208 & 1.301 & 201 \\
\hline
\end{tabular}

Berdasarkan tabel diatas menunjukan variabel mudharabah nilai signifikansinya adalah 0,635 , sedangkan variabel musyarakah nilai signifikansinya adalah 0,635 dan variabel murabahah nilai signifikansinya adalah 0,201 . Artinya milai signifikansi mudharabah $0,635>0,05$, musyarakah $0,635>0,05$ dan murabahah $0,201>0,05$. sehingga dapat disimpulkan bahwa untuk model regresi pada penelitian ini yakni pengaruh mudharabah, musyarakah dan murabahah terhadap profitabilitas menunjukan bahwa tidak terjadi masalah heteroskedastistas.

\section{d. Autokorelasi}

Dalam penelitian ini, dilakukan untuk mengetahui apakah terjadi autokorelasi atau tidak di dalam penelitian ini. Dalam pengujian penelitian ini menggunakan Uji Durbin Watson. Uji Durbin Watson merupakan uji autokorelasi yang dilakukan untuk mengetahui apakah ditemukan adanya autokorelasi pada nilai residual yang ada pada model regresi .

Untuk mengetahui ada atau tidaknya autokorelasi pada penelitian ini dapat dilihat pada tabel berikut:

\section{Tabel 4}

Hasil Autokorelasi

Model Summary ${ }^{b}$

\begin{tabular}{|l|r|r|r|r|r|}
\hline $\begin{array}{l}\text { Mo } \\
\text { del }\end{array}$ & $\mathrm{R}$ & $\mathrm{R}$ Square & $\begin{array}{c}\text { Adjusted } \mathrm{R} \\
\text { Square }\end{array}$ & $\begin{array}{c}\text { Std. Error of } \\
\text { the Estimate }\end{array}$ & Durbin-Watson \\
\hline 1 & $.531^{\circ}$ & .282 & .225 & .59531 & 2.022 \\
\hline
\end{tabular}

a. Predictors: (Constant), murabahah, mudharabah, musyarakah

b. Dependent Variable: profitabilitas

Pada tabel dapat dilihat bahwa nilai Durbin Watson pada penelitian ini adalah 2.022. DU < D < 4- DU atau $(1.6617<2.022<2.339)$ maka dapat disimpulkan tidak terdapat masalah autokorelasi.

\section{Analisis Data}

\section{a. Analisis Deskriptif}

Analisis deskriptif dilakukan sebagai gambaran umum menengenai objek penelitian yang dapat dijadikan sebagai sampel penelitian. Penelitian ini dengan menggunakan analisis deskriptif sangat diharapkan penjelasan ini dapat memberikan gambaran mengenai masalah yang diteliti. Analisis deskriptif difokuskan pad nilai maximum, minimum, rata-rata (mean), dan standar deviasi.

\section{Tabel 5}

\section{Hasil Analisis Deskriptif Descriptive Statistics}

\begin{tabular}{|c|c|c|c|c|c|}
\hline & $\mathrm{N}$ & Minimuma & Maximum & Mean & Sild. Deviation \\
\hline Mudharahah & 42 & 1.05 & 936.69 & $1.8924 \mathrm{E} 2$ & 291.07354 \\
\hline Musyarakah & 42 & 1.03 & 726.25 & 61.9091 & 130.45344 \\
\hline Mumabalah & 42 & 1.43 & 322.37 & 33.0155 & 73.15827 \\
\hline Profitabilitas & 42 & 02 & $23 \mathrm{~d}$ & $\$ 012$ & 67621 \\
\hline $\begin{array}{l}\text { Valid N } \\
\text { (listwise) }\end{array}$ & 42 & & & & \\
\hline
\end{tabular}

Berdasarkan tabel diatas menunjukan terdapat nilai $\mathrm{N}$ atau jumlah data dari setiap variabel yang berjumlah 42, dari 42 data sampel profitabilitas (Y), nilai minimum 0.42 , nilai maksimum 2.36 , hingga periode 2019 diketahui nilai mean sebesar 0.8012 , serta nilai standar deviation sebesar 0.67621 . Hal ini dikatakan bahwa nilai profitabilitas cukup baik.

1) Tabel diatas menunjukan nilai minimum mudharabah (X1) yang dihasilkan sebesar 1.05, sedangkan nilai maksimum sebesar 936.69 hingga periode 2019 dan diketahui nilai mean sebesar 1.8924, serta nilai standar deviation sebesar 291.07354. hal ini dikatakan bahwa nilai mudharabah cukup baik karena melebihi batas minimum.

2) Tabel diatas menunjukan nilai minimum musyarakah (X2) yang dihasilkan sebesar 1.03, nilai maksimum sebesar 726.25 hingga periode 2019 dan diketahui nilai mean sebesar 61.9091, serta nilai standar deviation sebesar 130.45344. 
hal ini dikatakan nilai musyarakah cukup baik.

3) Tabel diatas menunjukan nilai minimum murabahah (X3) yang dihasilkan sebesar 1.43, dan nilai maksimum sebesar 322.37 hingga periode 2019 dan diketahui nilai mean sebesar 33.0155 , serta nilai standar deviation sebesar 73.15827. hal ini dikatakan nilai murabahah cukup baik.

\section{b. Analisis Determinasi}

Analisis koefisien determinan bertujuan untuk mengetahui besarnya mengenai variabel bebas untuk memberikan penjelasan terhadap variabel terikat berdasarkan hasil output SPSS. Apabila, R2=0, yakni variabel bebas tidak memperlihatkan adanya hubungan terhadap variabel terikat. Dan, apabila R2= 1, yakni variabel-variabel bebas dapat memperlihatkan hubungan terhadap variabel terikat.

Tabel 6

Hasil Koefisien Determinasi Model Summary

\begin{tabular}{|l|l|r|r|r|}
\hline Model & $\mathrm{R}$ & $\mathrm{R}$ Square & Adjusted R Square & $\begin{array}{c}\text { Std. Error of the } \\
\text { Estimate }\end{array}$ \\
\hline 1 & $.531^{\mathrm{a}}$ & .282 & .225 & .59531 \\
\hline
\end{tabular}

a. Predictors: (Constant), murabahah, mudharabah, musyarakah

Berdasarkan output SPSS, jika dilihat pada tabel diatas. Koefiesien determinasi pada penelitian ini yaitu nilai $\mathrm{R}$ Square, dapat diketahui nilai $\mathrm{R}$ Square $=$ 0,282 . Nilai $R$ square tersebut berarti pembiayaan mudharabah, musyarakah dan murabahah mampu menjelaskan profitabilitas sebesar 0,282 atau $28,2 \%$.

\section{c. Analisis Regresi Linear Berganda}

Pada penelitian ini menggunakan model regresi linear berganda. Variabel bebas (independen) yakni, Mudharabah, Musyarakah dan Murabaha, sedangkan variabel terikat (dependen) yaitu profitabilitas. Berdasarkan hasil pengolahan ouput SPSS, dapat dilihat data mudharabah, musyarakah dan murabahah terhadap profitabilitas di peroleh hasil regresi sebagai berikut:

\section{Tabel 7}

Hasil Regresi Linear Berganda Coefficients $^{\mathrm{a}}$

\begin{tabular}{|c|c|c|c|c|c|}
\hline \multirow[t]{2}{*}{ Model } & \multicolumn{2}{|c|}{ Unstandardized Coefficients } & \multirow{2}{*}{$\begin{array}{c}\begin{array}{c}\text { Standardized } \\
\text { Coefficients }\end{array} \\
\text { Beta }\end{array}$} & \multirow[t]{2}{*}{$\mathrm{T}$} & \multirow[t]{2}{*}{ Sig. } \\
\hline & B & Std. Error & & & \\
\hline 1 (Constant) & .862 & .135 & & 6.394 & .000 \\
\hline Mudharabah & .000 & .000 & -170 & -1.208 & .236 \\
\hline Musyarakah & .002 & .001 & -314 & -2.202 & .034 \\
\hline Murabahah & .003 & 001 & 368 & 2.633 & .012 \\
\hline
\end{tabular}

Berdasarkan hasil pengolahan data pada tabel diatas, dapat dibentuk model prediksi variabel mudharabah, musyarakah dan murabahah terhadap profitabilitas sebagai berikut:

$$
\mathrm{Y}=0.862+0.000 \operatorname{In} \mathrm{X}_{1}-0.002 \operatorname{In} \mathrm{X}_{2}+0.003
$$

\section{Uji Statistik}

a. Uji Statistik F (simultan)

Pengujian variabel tidak hanya melakukan pengujian parsial, tetapi juga melakukan pengujian secara simultan atau uji F. Uji Simultan atau Uji F digunakan, dimaksudkan untuk menguji seberapa besarnya pengaruh variabel bebas terhadap variabel terikat, dengan nilai signifikan $0,05(\mathrm{a}=5 \%)$. Hasil pengolahan data dapat dilihat pada tabel 8 sebagai berikut:

\section{Tabel 8}

Hasil Uji Statistik F (Simultan)

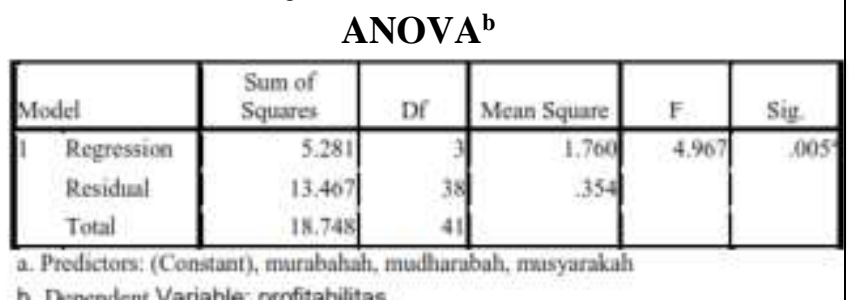

b. Dependent Variable: profitabilitas

Variabel independen yang digunakan dalam regresi yaitu mudharabah, musyarakah dan murabahah yakni untuk menjelaskan variabel independennya, yaitu profitabilitas. Dapat dilihat pada tabel diatas, dari tabel uji ANOVA menjelaskan bahwa nilai $\mathrm{F}$ hitung sebesar 4.967 dengan nilai signifikan 0,005 berdasarkan $\mathrm{F}$ tabel, jumlah sampel $(n)=42$, jumlah variabel $(k=3)$, maka didapatkan nilai $\mathrm{F}$ tabel sebesar 2,85. Karena tingkat signifikansi $<0,05(0,005<0,05)$ dan nilai $\mathrm{F}$ hitung $>\mathrm{F}$ tabel $(4,967>2,85)$ sehingga bisa disimpulkan bahwa H0 ditolak dan H1 diterima yang artinya ada pengaruh secara simultan mudharabah, musyarakah dan murabahah terhadap profitabilitas yang signifikan.

\section{b. Uji T (Parsial)}

Dalam penelitian ini, berdasarkan hasil ouput SPSS selain menggunakan uji simultan, dalam penelitian ini dilakukan uji pasial atau uji t untuk menguji besarnya pengaruh variabel bebas terhadap variabel terikat. Digunakan Uji parsial sebagai alat untuk mengetahui tingkat signfikansi pengaruh variabel bebas yaitu yang terdiri dari mudharabah, musyarakah dan murabahah secara parsial terhadap profitabilitas dengan tingkat signifikan 0,05 $(\mathrm{a}=5 \%)$. 
Berikut adalah hasil Uji t yang dilakukan menggunakan SPSS seperti tabel di bawah ini:

Tabel 9

Hasil Statistik Uji T

Coefficients $^{\mathrm{a}}$

\begin{tabular}{|c|c|c|c|c|c|}
\hline \multirow[b]{2}{*}{ Model } & \multicolumn{2}{|c|}{ Unstandardized Coefficients } & \multirow{2}{*}{$\begin{array}{c}\begin{array}{c}\text { Standandized } \\
\text { Coefficients }\end{array} \\
\text { Beta } \\
\end{array}$} & \multirow[b]{2}{*}{$\mathrm{T}$} & \multirow[b]{2}{*}{ Sige } \\
\hline & в & Std. Error & & & \\
\hline I (Constant) & 1862 & .135 & & 6.394 & .000 \\
\hline Mudharabah & .000 & 000 & -178 & -1.208 & .235 \\
\hline Musyarakah & -002 & .001 & -314 & -2.202 & .034 \\
\hline Murabuhah & .003 & 001 & 365 & 2633 & .012 \\
\hline
\end{tabular}

1) Hipotesis pertama

Berdasarkan tabel diatas, diketahui nilai Mudharabah menunjukan nilai koefisien $\mathrm{t}=$ 1,208 dengan nilai signifikansi 0,235 ,yang berarti menunjukan nilai signifikansi lebih dari 0,05. Sehingga bisa disimpulkan pembiayaan mudharabah secara parsial tidak berpengaruh negatif signifikan terhadap profitabilitas.

2) Hipotesis

Berdasarkan tabel diatas, diketahui nilai Musyarakah menunjukan nilai koefisien $t$ dengan sejumlah $=-2,202$, nilai signifikansi 0,034 ,yang berarti menunjukan nilai signifikansi kurang dari 0,05 . Sehingga bisa disimpulkan pembiayaan musyarakah secara parsial berpengaruh negatif signifikan terhadap profitabilitas.

3) Hipotesis ketiga

Berdasarkan tabel diatas, diketahui nilai Murabahah menunjukan nilai koefisien $\mathrm{t}$ sebesar 2,633 dengan nilai signifikansi 0,012 , yang berarti menunjukan nilai signifikansi kurang dari 0,05 . sehingga bisa disimpulkan pembiayaan murabahah berpengaruh positif signifikan terhadap profitabilitas.

\subsection{Pembahasan}

\section{Pengaruh Mudharabah terhadap profitabilitas}

Berdasarkan hasil pengujian statistik menunjukan secara parsial bahwa pembiayaan mudharabah tidak berpengaruh negatif signifikan terhadap profitabilitas. Uji parsial ini digunakan untuk menunjukan seberapa besarnya pengaruh mudharabah terhadap profitabilitas dengan menggunakan SPSS diperoleh $\mathrm{t}$ hitung sebesar $-1,208$ dan $\mathrm{t}$ tabel sebesar 2,024 dengan nilai signifikansi 0,235 artinya $-1,208$ $<2,024$ dan nilai signifikansi $0,235>0,05$. sehingga dapat disimpulkan bahwa pembiayaan mudharabah secara parsial tidak berpengaruh negatif signifikan terhadap prfitabilitas.

\section{Pengaruh musyarakah terhadap profitabilitas}

Berdasarkan hasil pengujian statistik secara parsial bahwa pembiayaan musyarakah berpengaruh negatif signifikan terhadap profitabilitas. Hal ini dilakukan untuk mengetahui besarnya perngaruh musyarakah terhadap profitabilitas dengan menggunakan output SPSS diperoleh $\mathrm{t}$ hitung sebesar -2,202 dan $t$ tabel sebesar 2,024 dengan nilai signifikansi 0,034 artinya $-2,205<2,024$ dan nilai signifikansi $0,034<0,05$. sehingga dapat disimpulkan bahwa secara parsial Musyarakah berpengaruh negatif signifikan terhadap profitabilitas. Pengaruh Murabahah terhadap profitabilitas

Berdasarkan hasil pengujian statistik secara parsial bahwa pembiayaan murabahah berpengaruh positif signifikan terhadap profitabilitas. Hal ini dilakukan untuk mengetahui seberapa besarnya pengaruh murabahah terhadap profitabilitas dengan menggunakan SPSS diperoleh $\mathrm{t}$ hitung 2,633 dan $\mathrm{t}$ tabel sebesar 2,024 dengan nilai signifikansi 0,012 artinya $2,633<2,024$ dan nilai signifikansi $0,012<$ 0,05 . sehingga dapat disimpulkkan bahwa secara parsial murabahah berpengaruh positif signifikan terhadap profitabilitas.

\section{KESIMPULAN}

Berdasarkan hasil analisis dapat diambil kesimpulan sebagai berikut:

Pertama, berdasarkan uji statistik secara parsial menunjukan bahwa pembiayaan mudharabah tidak memiliki pengaruh negatif signifikan terhadap profitabilitas pada Bank Umum Syariah. Hal ini menandakan bahwa semakin meningkatnya nilai mudharabah yang dilakukan oleh bank, maka akan semakin tinggi pula tingkat profit pada suatu bank.

Kedua, berdasarkan uji statistik secara parsial menunjukan bahwa pembiayaan musyarakah memiliki pengaruh negatif signifikan terhadap profitabilitas pada Bank Umum Syariah .Hal ini menandakan bahwa pembiayaan musyarakah berpengaruh pada Bank Umum syariah dan juga berpengaruh terhadap nilai profit bank namun pengaruhnya sangat rendah.Hal ini menunjukan bahwa Semakin bertambah tingkat pembiayaan musyarakah,maka akan menurunkan profitabilitas yang diperoleh Bank Umum Syariah.

Ketiga,berdasarkan uji statistik secara parsial menunjukan bahwa pembiayaan murabahah memiliki pengaruh positif signifikan terhadap profitabilitas 
pada Bank Umum Syariah. Hal ini disebabkan karena pembiayaan ini sangat diminati masyarakat serta memiliki margin yang relatif dapat dipastikan dan resikonya dapat dikelola.

\section{UCAPAN TERIMA KASIH}

Diucapkan terima kasih kepada semua pihak yang telah berkontribusi dalam penelitian ini, sehingga penelitian ini dapat terlaksana dengan baik.

\section{REFERENSI}

Faradilla, C., Arfan, M., \& Shabri, M. (2017). Pengaruh pembiayaan murabahah, istishna, ijarah, mudharabah dan musyarakah terhadap profitabilitas bank umum syariah di indonesia. Jurnal Magister Akuntansi Universitas Syiah Kuala Vol. 6, No. 3.

Anjani, R., \& Maulidiyah, Indira, H. (2016) .Pengaruh Pembiayaan Mudharabah, Musyarakah Dan Murabahah Terhadap Profitabilitas Bprs Di Indonesia Periode 2012-2015. Jurnal: Universitas Muhammadiyah Surakarta, 2016.

Romdhoni, A. H., \& Ferlangga, A. Y. (2018). Pengaruh Pembiayaan Mudharabah, Musyarakah dan Ijarah Terhadap Profitabilitas Bank Muamalat Indonesia. Jurnal Ilmiah Ekonomi Islam.

Sirat, A. H., Muchsin, N. Bailusy., \& Saiful, L. R.(2018) Pengaruh Pembiayaan Mudharabah, Musyarakah, Murabahah Dan Ijarah Terhadap Profitabilitas Bank Umum Syariah (Bus) Yang Terdaftar Di Otoritas Jasa Keuangan (Ojk). Jurnal Managemen Sinergi Vol. 5, No. 2.
Satria, D., I \& Haryati, S. (2016). Pengaruh Pendapatan Murabahah, Mudharabah, Dan Musyarakah Terhadap Return On Equity Pt Bank Syariah Mandiri. Jurnal Visioner \& Strategis Vol. 5, No. 2.

Rahmarini, N.( 2020). Pengaruh Pembiayaan Murabahah, Musyarakah,Mudharabah, Dan Ijarah Terhadap Profitabilitas (Roa) Pada Bank Umum Syariah Di Indonesia Periode 2016-2019. Jurnal Ilmiah Sekolah Tinggi Ilmu Ekonomi Perbanas Surabaya.

Fadholi, A. D. (2015). Pengaruh Pembiayaan Murabahah, Musyarakah dan Mudharabah Terhadap Profitabilitas Bank Umum Syariah (Studi Empiris Pada Bank Umum Syariah di Indonesia Tahun 2011-2014). Jurnal Ilmiah Universitas Muhammadiyah Surakarta.

Sari, D. W, Anshori M. Y. (2017). Pengaruh Pembiayaan Murabahah, Istishna, Mudharabah, Dan Musyarakah Terhadap Accounting and Management. Journal, Vol. 1, No. 1.

Asih, Y.(2019). Analisis Pengaruh Pembiayaan Mudharabah, Musyarakah, Murabahah Dan Ijarah Terhadap Profitabilitas Bank Umum Syariah Di Indonesia Periode 2014-2018. Jurnal Universitas Muhammadiyah Magelang.

Antonio, M. S. I. (2001). Bank Syariah: Dari teori ke praktik. Gema Insani

Nurhayati, S. dan Wasilah. (2011). Akuntansi Syariah di Indonesia. Jakarta: Salemba Empat. 